\title{
Development of an expert system for selection of multiphase flow correlations
}

\author{
Mohamed A. Abd El-Moniem ${ }^{1}$. Ahmed H. El-Banbi ${ }^{2}$
}

Received: 17 September 2017 / Accepted: 6 February 2018 / Published online: 15 February 2018

(c) The Author(s) 2018. This article is an open access publication

\begin{abstract}
Our target was to develop an expert system to help petroleum engineers in selecting the most suitable multiphase flow correlation in the absence of measured flowing pressure. A large database of pressure points was collected and analyzed using many multiphase flow correlations. The expert system was developed with a set of rules to identify the best correlation for variety of well, flow, and PVT conditions. The expert system is based on the idea of clustering the data and finding the best multiphase flow correlation(s) for each cluster. The error associated with the selected correlation is also quantified for every correlation in each data sub-cluster so the engineer would expect the accuracy of pressure drop prediction when utilizing this approach. Over the entire database, if one multiphase flow correlation is selected, the overall mean absolute percent error ranges between 12.7 and $57.5 \%$, while the range of errors for best correlation(s) in different data sub-clusters range from 0.01 to $3 \%$ for most cases with accurate PVT. The expert system was validated by a new set of data. It succeeded in identifying the best correlation(s) $70 \%$ of the times, and the calculated pressure was more accurate than using one correlation by a factor of 2. Use of the expert system in the validation database gave a mean absolute percent error of $8.8 \%$. This represents approximately one-third of the error value when any single correlation is used over the entire validation dataset. (Error for using single correlation ranges from more than 21 to $29 \%$.)
\end{abstract}

Keywords Multiphase flow $\cdot$ Out flow performance $\cdot$ Multiphase correlations $\cdot$ Production engineering $\cdot$ Nodal analysis

\section{List of symbols}

API

$A_{t} \quad$ Actual flowing pressure data

bbl Barrel

Begg Beggs and Brill correlation

BHT Bottom-hole temperature

d Diameter

D Day

DRM Duns and Ros modified correlation

DRO Duns and Ros original correlation

ESP Electrical submersible pump

FB Fancher and Brown correlation

Electronic supplementary material The online version of this article (https://doi.org/10.1007/s13202-018-0442-7) contains supplementary material, which is available to authorized users.

Mohamed A. Abd El-Moniem

eng_mohamedali1986@yahoo.com

1 Amal Petroleum Company, Cairo, Egypt

2 Cairo University, Giza, Egypt
FT Foot

$F_{t} \quad$ Forecasted flowing pressure data from different 14 correlations

${ }^{\circ} \mathrm{F} \quad$ Degree Fahrenheit

GOR Gas/oil ratio

GRE GRE correlation

HB Hagedorn and Brown correlation

HYDRO HYDRO correlation

in Inch

ID Inner diameter

MAPE Mean absolute percent error

MPE Mean percent error

MB Mukherjee and Brill correlation

$n \quad$ Number of data points

OD Outer diameter

ORK Orkiszewski correlation

PET Petroleum experts correlation

PET 2 Petroleum experts 2 correlation

PET 3 Petroleum experts 3 correlation

PET 4 Petroleum experts 4 correlation

PET 5 Petroleum experts 5 correlation

$q_{\mathrm{L}} \quad$ Liquid flow rate 


$\begin{array}{ll}q_{\mathrm{o}} & \text { Oil flow rate } \\ \text { scf } & \text { Standard cubic feet } \\ \text { T.S. } & \text { Tubing size } \\ \text { W.C. } & \text { Water cut } \\ \mathrm{Vg} & \text { Gas specific gravity } \\ \varepsilon & \text { Pipe roughness } \\ \% & \text { Percentage }\end{array}$

\section{Introduction}

Multiphase flow correlations are routinely used to calculate pressure (and temperature) drop in the tubing and flow lines for production and injection wells. The pressure drop calculations have many applications in artificial lift design and optimization, well deliverability forecasting, and flow assurance applications. Over several decades, many investigators developed multiphase flow correlations to calculate pressure drop in tubing at variety of conditions. Each correlation was derived for certain conditions. Several comparison studies between different correlations for specific sets of data are also available in the literature. Predicting multiphase flow pressure drop can sometimes present a challenge for practicing engineers.

Multiphase flow occurs due to the variations of phases that flow through one pipe. These phases may be oil, water, and gas. Due to the different properties of gas compared with oil and water for viscosities and other properties, the gas tends to flow faster than oil and past the liquid in the upward flow (gas slippage). The in situ liquid volume in the pipe is defined as the liquid holdup.

The pressure drop calculations depend on the properties of the mixture of liquid including oil and water in addition to the gas. The total pressure drop is equal to the summation of the hydrostatic, friction, and acceleration pressure drops. The hydrostatic term depends on the mixture density, which is a function of the liquid holdup. The friction term depends on the friction factor for the mixture. The acceleration term appears due to the change in velocity resulting from the change in pressure. The friction calculations depend on the flow regime, which in turn depends on the superficial velocity of liquid and gas phases.

The most common flow regimes for vertical wells include single liquid flow, bubble, slug, churn, annular, and mist flow. The possible flow regimes for horizontal wells usually include dispersed bubble, annular, slug, stratified wavy, and stratified smooth.

Over the years, both empirical correlations and mechanistic models were derived to calculate the pressure drop in pipes. Empirical correlations can be classified into three categories (Ansari et al. 1990):
1. Correlations that assume no slip and do not consider flow patterns. Examples include Poettmann and Carpenter (1952) and Fancher and Brown (1963).

2. Correlations that consider the slip but not the flow patterns. Examples include Gray (1978) and Hagedorn and Brown (1964 and 1965), etc.

3. Correlations that consider both the slip and the flow patterns. Examples include correlations by Duns and Ros (1963) and Beggs and Brill (1973).

The mechanistic models, however, usually include some physical phenomena with analytical relations to predict the flow patterns. In these models, mostly analytical expressions are used to calculate the different parameters for each flow regime. Examples for mechanistic models include Aziz et al. (1972) and Ansari et al. (1990).

Although many correlations to calculate the pressure drop in pipes are available, clear rules on how to select appropriate correlations do not exist in the absence of actual pressure measurements. In this work, an expert system is developed to select the best correlation(s) for specific well and flow conditions.

\section{Expert system development}

The first step in developing the expert system was to collect a large database of pressure drop points covering a wide variety of well and flow conditions.

Abd El-Moniem (2016) and Abd El-Moniem and ElBanbi (2015) collected bottom-hole flowing pressure data points from both the literature from Ashiem (1986), Baxendell and Thomas (1961), Chierici et al. (1974), Hill and Wood (1994), Peffer et al. (1988) and Reinicke et al. (1987) and actual oil wells covering different well and flow conditions. The current study used around 2730 oil well data points for developing the expert system and 144 different

Table 1 Range of data used in developing and validating the expert system

\begin{tabular}{|c|c|c|c|}
\hline \multicolumn{2}{|c|}{$\begin{array}{l}\text { Data for development of the expert } \\
\text { system ( } 2730 \text { points) }\end{array}$} & \multicolumn{2}{|c|}{$\begin{array}{l}\text { Data for validation of the expert } \\
\text { system (144 points) }\end{array}$} \\
\hline Property & Range & Property & Range \\
\hline qo, bbl/D & $5-36,800$ & qo, bbl/D & $15-31,427$ \\
\hline GOR, scf/bbl & $0-40,000$ & GOR, scf/bbl & $223-6081$ \\
\hline W.C., \% & 0-98 & W.C., \% & $0-76$ \\
\hline $\mathrm{BHT},{ }^{\circ} \mathrm{F}$ & $82-370$ & $\mathrm{BHT},{ }^{\circ} \mathrm{F}$ & $121-264$ \\
\hline $\mathrm{API},{ }^{\circ}$ & $8-60$ & API, ${ }^{\circ}$ & $13-46.5$ \\
\hline yg & $0.57-1.81$ & yg & $0.57-0.93$ \\
\hline Depth, ft. & $250-14,358$ & Depth, ft. & $650-12,862$ \\
\hline
\end{tabular}


data points for its validation. The range of the data is listed in Table 1.

To cover all the points in the database, more than 560 well models were developed using a commercial pipe modeling software. We performed around 1042 simulation runs and calculated the predicted bottom-hole flowing pressure using 14 different correlations for each point. We, then, calculated the error from each correlation for each point.

Table 2 shows the average and mean absolute percent error for each correlation through the entire database. The minimum and maximum absolute percent errors are also shown. The mean absolute percent error ranges from 12.67 to 57.52 for the best and worst correlation over the entire dataset. More importantly, the table shows large range of error between minimum and maximum errors for all correlations.

As shown in Figs. 1 and 2 as examples, we show the error for two selected correlations for all the data points in the database to show the correlation performance for different points. The large variations in the error (some points show very small error, while other points show very large error); we can conclude that no correlation is good for all the points within the database. However, each correlation has reasonable prediction capabilities for some range of well and flow
Table 2 Average error and average absolute error of the different fourteen correlations for the entire database
Fig. 1 Hagedorn and Brown correlation performance through the entire database

\begin{tabular}{|c|c|c|c|c|}
\hline \multirow{2}{*}{$\begin{array}{l}\text { Correlation } \\
\text { Prosper Software Help } \\
\text { Manual, Petroleum Experts } \\
\text { (2013) }\end{array}$} & \multicolumn{4}{|c|}{ Database for development of the expert system (2730 points) } \\
\hline & $\begin{array}{l}\text { Mean percent } \\
\text { error } \%\end{array}$ & $\begin{array}{l}\text { Mean absolute } \\
\text { percent error \% }\end{array}$ & $\begin{array}{l}\text { Minimum absolute } \\
\text { error } \%\end{array}$ & $\begin{array}{l}\text { Maximum } \\
\text { absolute error } \\
\%\end{array}$ \\
\hline Duns and Ros modified & 11.09 & 19.42 & 0.02 & 729.68 \\
\hline Hagedorn and Brown & -4.74 & 13.68 & 0.00 & 466.54 \\
\hline Fancher and Brown & -10.38 & 16.53 & 0.01 & 408.25 \\
\hline Mukherjee and Brill (1983) & 3.85 & 14.54 & 0.02 & 481.03 \\
\hline Beggs and Brill & 8.38 & 13.93 & 0.00 & 712.03 \\
\hline Petroleum experts & -1.61 & 13.31 & 0.01 & 605.45 \\
\hline Orkiszewski (1967) & -5.53 & 15.23 & 0.00 & 737.27 \\
\hline Petroleum experts 2 & -0.80 & 12.88 & 0.00 & 568.50 \\
\hline Duns and Ros original & 2.82 & 12.81 & 0.00 & 321.14 \\
\hline Petroleum experts 3 & -4.82 & 13.46 & 0.00 & 511.42 \\
\hline GRE & -0.75 & 12.69 & 0.00 & 582.91 \\
\hline Petroleum experts 4 & -2.73 & 13.34 & 0.00 & 320.65 \\
\hline Hydro 3P & 49.16 & 57.52 & 0.00 & 954.75 \\
\hline Petroleum experts 5 & -0.75 & 12.67 & 0.00 & 586.94 \\
\hline
\end{tabular}

\section{HB Correlation Performance}

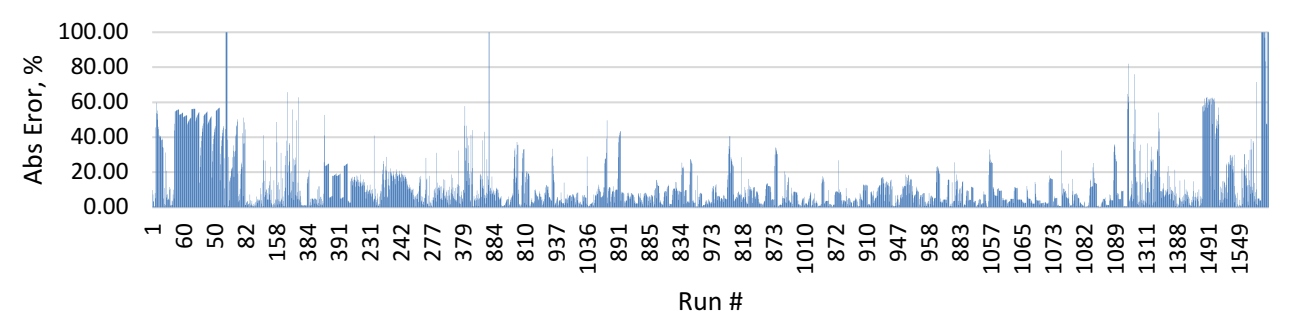

Run \#

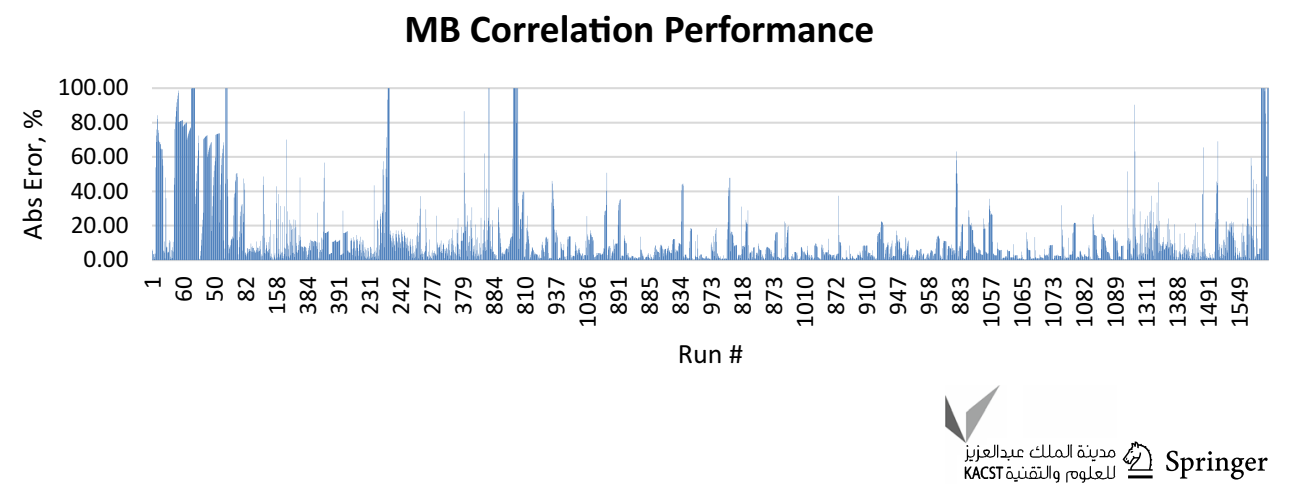

Fig. 2 Mukherjee and Brill correlation performance through the entire database 


\section{New Clusters Map Oil Wells}

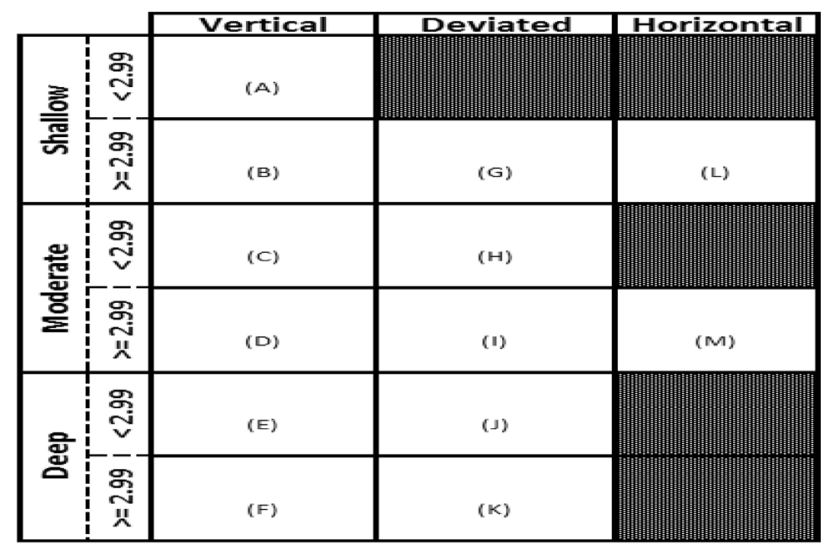

Fig. 3 Clusters map

Table 3 Sub-clusters production criteria for oil wells [after Abd ElMoniem and El-Banbi (2015)]

\begin{tabular}{lll}
\hline qo, bbl/D & W.C., $\%$ & GOR, scf/bbl \\
\hline$<2500$ & $<5$ & $<1000$ \\
$2500-10,000$ & $5-30$ & $1000-5000$ \\
$>10,000$ & $30-70$ & $>5000$ \\
& $>70$ & \\
\hline
\end{tabular}

conditions. Our objective was to divide the data into clusters (groups) and to identify the best correlation(s) within each data cluster.

The database was divided into clusters according to well depth, well geometry and tubing size as shown in Fig. 3.

Shallow depth is for points that are less than $2000 \mathrm{ft}$. TVD, deep is for pressure points that are more than $9000 \mathrm{ft}$. in depth, and the moderate depth is between.

We, then, divided the data into sub-clusters according to production criteria. Table 3 shows the selected criteria based on oil rate, water cut, and GOR. Therefore, each cluster of the major ones in Fig. 3 was further divided into smaller segments (sub-cluster) representing the different production conditions given in Table 3 . The selection of cluster and subcluster ranges was essentially arbitrary. However, we wanted to make sure enough data points were available for every cluster and sub-cluster. We also wanted to have the cluster and sub-clusters bounded by easy values to remember.

These sub-clusters within the clusters were given different code numbers (reference numbers) as listed in Table 4. Each segment of data is then defined by which cluster it lies in and its reference number (sub-cluster number). Table 4 also contains the number of data points available for every sub-cluster. The number of data points is given in the green cells. The sub-clusters represented by the red cells did not contain data points.

A Microsoft Access program was developed for the entire dataset to store the actual values of pressure, calculated values from all 14 correlations, and the error for every point. The Access Database was then used to extract a total of 131 sub-clusters for tubular flow and identify the best correlation(s) in each sub-cluster.

The clusters (13) are divided based on geometry (well depth, well deviation, and ID). The sub-clusters division is based on flow conditions (oil rate, WC, and GOR). According to these divisions, we should theoretically have $13 \times 36$ sub-cluster. However, many sub-clusters did not contain data (e.g., it is not possible to have high oil rate wells with small ID, and it is not possible to have high GOR wells with high oil rate and high WC). The sub-clusters that contained enough data points to draw conclusions were 131 .

As listed in Table 4, some sub-cluster contained large number of data points, and others contained fewer data points. We further classified the sub-clusters according to how many points they had into three categories:

1. Strong sub-cluster containing more than 20 points.

2. Moderate sub-cluster containing between 5 and 20 points.

3. Weak sub-cluster containing less than 5 points.

The identification of different levels of correlation strength was covered by defining a correlation "strength factor" and covered in Abd El-Moniem and El-Banbi (2015). They also reported the error for every correlation in every sub-cluster.

\section{Results}

The detailed results of sub-clusters can be found in Abd ElMoniem (2016). A sample of the results is listed in Table 5. The tables given in the paper and the appendix are sufficient to fully utilize the expert system.

\section{Application of the expert system}

The use of the expert system is based on selecting the appropriate cluster as shown in Fig. 3. The selection of the cluster is based on (1) well type (vertical, deviated, or horizontal), (2) tubing size, and (3) depth. The following step is to select the sub-cluster based on (4) oil production rate, (5) gas/oil ratio (GOR), and (6) water cut as listed in Table 4. The sub-cluster is determined from Fig. 3 and Table 4. The detailed sub-cluster tables to determine the best correlation, its strength, and expected error range are given in "Appendix 
Table 4 Sub-clusters reference number and data points for oil wells

\begin{tabular}{|c|c|c|c|c|c|c|c|c|c|c|c|c|c|c|c|c|}
\hline \multicolumn{3}{|c|}{ Criteria } & \multirow{3}{*}{$\begin{array}{c}\text { Reference } \\
\text { Number }\end{array}$} & \multirow{2}{*}{\multicolumn{13}{|c|}{ Cluster Number, Data Availability and Number of Points }} \\
\hline \multirow{2}{*}{$\begin{array}{c}\text { qo } \\
\text { “bbl/D” }\end{array}$} & \multirow{2}{*}{$\begin{array}{c}\text { GOR } \\
\text { “scf/bbl” }\end{array}$} & \multirow{2}{*}{$\begin{array}{l}\text { W.C. } \\
\text { “\%” }\end{array}$} & & & & & & & & & & & & & & \\
\hline & & & & A & B & C & D & $\mathbf{E}$ & $\mathbf{F}$ & G & H & I & $\mathbf{J}$ & $\mathbf{K}$ & $\mathbf{L}$ & M \\
\hline \multirow{12}{*}{$<2,500$} & \multirow{4}{*}{$<1,000$} & $<5$ & 1 & 29 & 73 & 99 & 154 & 25 & 9 & 23 & 23 & 84 & 2 & 2 & 6 & 10 \\
\hline & & $5-30$ & 2 & 2 & 42 & 30 & 137 & 1 & 6 & 19 & 7 & 52 & & 1 & & \\
\hline & & $30-70$ & 3 & 6 & 168 & 28 & 414 & 9 & 5 & 17 & 7 & 108 & & & 4 & 6 \\
\hline & & $>70$ & 4 & & 13 & 9 & 60 & 3 & 8 & 4 & 6 & 25 & & & & \\
\hline & \multirow{4}{*}{$\begin{array}{l}8 \\
8 \\
0 \\
\text { டி } \\
8 \\
0 \\
-\end{array}$} & $<5$ & 5 & & 7 & 17 & 16 & 19 & 4 & & 1 & 69 & 4 & & & \\
\hline & & $5-30$ & 6 & & 2 & 1 & 10 & 2 & 14 & & & 1 & & 7 & & \\
\hline & & $30-70$ & 7 & 2 & 24 & 1 & 84 & & & 2 & & 18 & 2 & 14 & & \\
\hline & & $>70$ & 8 & 4 & & 2 & & & & 2 & & 7 & & 6 & & \\
\hline & \multirow{4}{*}{$>5,000$} & $<5$ & 9 & & & 1 & 2 & 2 & & & & 7 & & & & \\
\hline & & $5-30$ & 10 & & & 1 & 1 & & & & & 4 & & 2 & & \\
\hline & & $30-70$ & 11 & & & 1 & & & & 2 & & 6 & & & & \\
\hline & & $>70$ & 12 & & & 8 & & & & 3 & & 25 & 1 & 19 & & \\
\hline \multirow{12}{*}{ 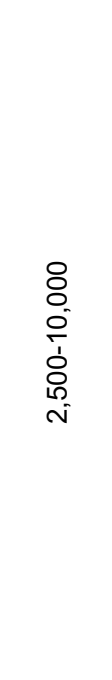 } & \multirow{4}{*}{$<1,000$} & $<5$ & 13 & 22 & 69 & 36 & 118 & 4 & 10 & 7 & 3 & 24 & & 8 & 8 & 16 \\
\hline & & $5-30$ & 14 & & 14 & 3 & 37 & 3 & & . & & 5 & & & 2 & 7 \\
\hline & & $30-70$ & 15 & & 5 & 1 & 12 & 5 & & & & & & & & \\
\hline & & $>70$ & 16 & & & & & & & & & & & & & \\
\hline & \multirow{4}{*}{$\begin{array}{l}8 \\
8 \\
8 \\
0 \\
8 \\
8 \\
8\end{array}$} & $<5$ & 17 & & & & 1 & & 2 & 4 & 2 & 3 & 1 & 16 & & \\
\hline & & $5-30$ & 18 & & & & & 2 & & & & & & & & \\
\hline & & $30-70$ & 19 & & & & & & & & & 1 & & & & \\
\hline & & $>70$ & 20 & & & & & & & & & & & & & \\
\hline & \multirow{4}{*}{$>5,000$} & $<5$ & 21 & & & & & & & & & & & 1 & & \\
\hline & & $5-30$ & 22 & & & & & & & & & & & & & \\
\hline & & $30-70$ & 23 & & & & & & & & & & & & & \\
\hline & & $>70$ & 24 & & & & & & & & & & & & & \\
\hline
\end{tabular}

A." An example on how to use the expert system is also given in "Appendix B."

We also developed a VBA (Visual Basic code) for Microsoft Excel to facilitate the selection of the appropriate correlation. The user can input the six inputs required by the expert system, and the VBA code will automatically find the following information: (1) the cluster and sub-cluster where the user data point is located, (2) the multiphase correlation(s) that should be used to predict the pressure drop for this particular data point, (3) the expected error of this best correlation(s) in the database, and (4) the strength factor for the selected correlation(s) within the sub-cluster. The authors can share the VBA code with interested readers.
An example run of the VBA code is shown in Fig. 4. The expert system run for this example case came up with two best correlations (not one). The strength factor for the first correlation (MB) is $43 \%$, and the strength factor for the second correlation (HYDRO) is $35 \%$. It is the same for the mean absolute percent error (1.54\% for MB and $2.22 \%$ for HYDRO).

\section{Validation of the expert system}

A new dataset with 144 points from 62 wells was used in validating the expert system. All these data points were not used in developing the expert system. The validation dataset was distributed among 48 sub-clusters of data. All 14 
Table 4 (continued)

\begin{tabular}{|c|c|c|c|c|c|c|c|c|c|c|c|c|c|c|c|c|}
\hline \multicolumn{3}{|c|}{ Criteria } & \multirow{3}{*}{$\begin{array}{l}\text { Reference } \\
\text { Number }\end{array}$} & \multirow{2}{*}{\multicolumn{13}{|c|}{ Cluster Number and Data Availability }} \\
\hline \multirow{2}{*}{$\begin{array}{c}\text { qo } \\
\text { “bbl/D” }\end{array}$} & \multirow{2}{*}{$\begin{array}{c}\text { GOR } \\
\text { “scf/bbl” }\end{array}$} & \multirow{2}{*}{$\begin{array}{l}\text { W.C. } \\
\text { “\%” }\end{array}$} & & & & & & & & & & & & & & \\
\hline & & & & A & B & C & D & E & $\mathbf{F}$ & G & H & I & $\mathbf{J}$ & K & $\mathbf{L}$ & M \\
\hline \multirow{12}{*}{$>10,000$} & \multirow{4}{*}{$<1,000$} & $<5$ & 25 & & & 1 & 2 & 7 & & & & 23 & & 5 & 2 & 6 \\
\hline & & $5-30$ & 26 & & & & & 4 & & & & & & & & \\
\hline & & $30-70$ & 27 & & & & & & & & & & & & & \\
\hline & & $>70$ & 28 & & & & & & & & & & & & & \\
\hline & \multirow{4}{*}{$1,000-5,000$} & $<5$ & 29 & & & & & 1 & 2 & & & & & 18 & & \\
\hline & & $5-30$ & 30 & & & & & & & & & & & & & \\
\hline & & $30-70$ & 31 & & & & & & & & & & & & & \\
\hline & & $>70$ & 32 & & & & & & & & & & & & & \\
\hline & \multirow{4}{*}{$>5,000$} & $<5$ & 33 & & & & & & & & & & & 1 & & \\
\hline & & $5-30$ & 34 & & & & & & & & & & & & & \\
\hline & & $30-70$ & 35 & & & & & & & & & & & & & \\
\hline & & $>70$ & 36 & & & & & & & & & & & & & \\
\hline
\end{tabular}

Table 5 Sample of complete results for one sub-cluster [after Abd El-Moniem and El-Banbi (2015)]

\begin{tabular}{|l|c|c|c|c|c|}
\hline \multicolumn{1}{|c|}{ Correlation } & No. of Points & Strength (\%) & Avg. Error (\%) & Avg. Abs. Error (\%) \\
\hline DRO & 15 & & 65 & 0.17 & 1.24 \\
\hline ORK & 12 & 0 & 52 & 0.39 & 1.80 \\
\hline PET2 & 10 & 0 & 43 & -0.84 & 1.23 \\
\hline PET4 & 9 & 0 & 39 & 0.03 & 0.86 \\
\hline DRM & 9 & 0 & 39 & 0.16 & 1.61 \\
\hline PET5 & 8 & 0 & 35 & -0.20 & 0.77 \\
\hline GRE & 8 & 0 & 35 & -0.51 & 0.82 \\
\hline PET & 8 & 0 & 35 & -0.13 & 0.88 \\
\hline HB & 6 & 0 & 26 & -0.10 & 0.75 \\
\hline PET3 & 6 & 0 & 26 & -0.10 & 0.75 \\
\hline BEGG & 6 & 0 & 26 & -0.10 & 0.75 \\
\hline MB & 6 & 0 & 26 & -0.97 & 1.46 \\
\hline \multicolumn{1}{|c|}{ Total Points } & 4 & 0 & 17 & -0.28 & 1.08 \\
\hline
\end{tabular}

correlations were run for all 144 points, and the best correlation (and its error) was determined for each point. The expert system was also run for all 144 points, and the best correlation selected by the expert system was compared to the best correlation based on the error calculation. The expert system validation was done on two levels. First, Table 6 shows a summary for all 144 points, and it shows that the expert system was able to predict the best correlation in $70 \%$ of the cases. Secondly, the predicted correlation by the expert system was used to compute the pressure drop for every point in the 144 points. Equations (1) and (2) are used to calculate the mean absolute percent error and the mean percent error.
MAPE $=\frac{100}{n} \sum_{i=1}^{n}\left|\frac{A_{t}-F_{t}}{A_{t}}\right|$

$\mathrm{MPE}=\frac{100}{n} \sum_{i=1}^{n} \frac{A_{t}-F_{t}}{A_{t}}$

Table 7 shows the error results for the expert system prediction over the 144 points (whether the predicted correlation from the expert system was the best one or not) in comparison with each correlation error over the same data (144 data 


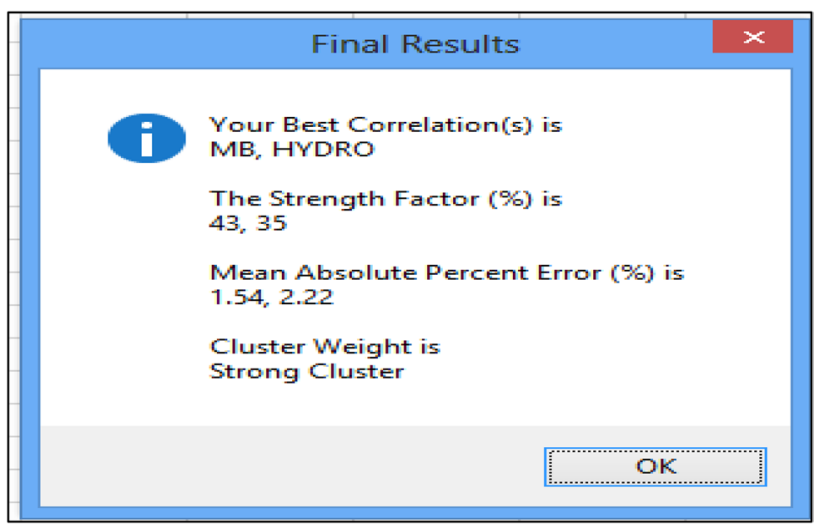

Fig. 4 Expert system best correlation/strength factor/mean absolute percent error output window

Table 6 Expert system validated points status

\begin{tabular}{|c|c|c|}
\hline Status of The Point & Number of Points & $\begin{array}{c}\text { Percentage } \\
\%\end{array}$ \\
\hline Match & 101 & 70 \\
\hline No Match & 43 & 30 \\
\hline Total & \multicolumn{2}{|l|}{144} \\
\hline
\end{tabular}

Table 7 Performance results of the expert system versus all correlations for validation dataset

\begin{tabular}{lrl}
\hline Correlation & $\begin{array}{c}\text { Mean percent } \\
\text { error \% }\end{array}$ & $\begin{array}{l}\text { Mean absolute } \\
\text { percent error \% }\end{array}$ \\
\hline Expert system & -0.22 & 8.82 \\
Duns and Ros modified & 17.16 & 28.06 \\
Hagedorn and Brown & 5.81 & 24.14 \\
Fancher and Brown & -2.04 & 29.18 \\
Mukherjee and Brill & 14.55 & 21.20 \\
Beggs and Brill & 17.53 & 22.16 \\
Petroleum experts & 8.55 & 23.16 \\
Orkiszewski & 2.83 & 25.79 \\
Petroleum experts 2 & 9.47 & 23.30 \\
Duns and Ros original & 13.77 & 21.59 \\
Petroleum experts 3 & 5.18 & 24.88 \\
GRE & 8.70 & 22.65 \\
Petroleum experts 4 & 9.76 & 21.96 \\
Hydro 3P & 11.07 & 21.74 \\
Petroleum experts 5 & 9.27 & 22.33 \\
\hline
\end{tabular}

points). The mean absolute percent error is around 8.8\% using the expert system compared to more than $21 \%$ for the best single correlation over the validation dataset. The validation results also show that even in the cases where the best correlation was not selected by the expert system (30\% of the cases), the selected correlation always produced reasonably good results compared with the actual values (i.e., when the expert system fails to select the absolute best correlation, it will select one of the second best correlations).

\section{Sensitivity of the expert system to uncertain input parameters}

In this section, we wanted to test the strength of the expert system and how it reacts to inaccurate input data. The measured GOR is usually among the most uncertain parameters in oil well operations. Other parameters that may carry some uncertainty include API gravity of the oil, specific gravity of the gas, and tubing roughness. In each one of these four parameters, a random subset of the database was used to test the effect of the parameter sensitivity on the expert system accuracy. In the sensitivity analysis study, we used a randomly selected dataset out of the database. We made sure the selected dataset covered points from most sub-clusters. The sensitivity analysis work involves changing a parameter (e.g., GOR or API) and running all correlations again with the new value for GOR or API, then extracting the data, calculating errors, and comparing correlations with actual data. Enough points were tested to validate and generalize the conclusions regarding the effect of these parameters.

For each point within the subset of the database, the parameter was perturbed by $10-20 \%$ and the expert system was run to predict the best correlation(s). The suggested correlation by the expert system was also used (with the perturbed input parameter) to predict the pressure drop and compared with the actual value of the pressure. The following paragraphs summarize our findings from the sensitivity study.

\section{GOR sensitivity}

GOR affects both the input to the expert system and the input to correlation calculations. Four groups of wells were selected: (1) low GOR and high oil rate wells, (2) high GOR 
and high oil rate wells, (3) low GOR and low oil rate wells, and (4) high GOR and low oil rate wells.

For low GOR and high rate wells, the expert system could predict the best correlation with a success rate of $56 \%$, when the GOR input (one of the sensitive input parameters) was changed by $\pm 20 \%$. This reflects that changing GOR for low GOR high rate wells has a moderate effect in changing the order of the best correlation.

For high GOR and high rate wells, the expert system could predict the best correlation by $75 \%$. It reflects that changing GOR for high GOR high rate wells by a percentage of $\pm 20 \%$ has a slight effect in changing the order of the best correlation.

For low GOR and low rate wells, the expert system could predict the best correlation by $37.5 \%$. It reflects that changing GOR for low GOR low rate wells by a percentage of $\pm 20 \%$ has a significant effect in changing the order of the best correlation.

For high GOR and low rate wells, the expert system could predict the best correlation $95 \%$ of the cases. We can safely conclude that $\mathrm{a} \pm 20 \%$ error in GOR for those wells had minor effect in changing the order of the best correlation.

GOR was found to have considerable effect on the calculated pressure drop from all correlations, especially for low GOR wells (in both high oil rate and low oil rate wells). This is probably due to changing flow regimes in the calculation of pressure drop. Although GOR here is the producing GOR, solution gas/oil ratio (Rs) is responsible for part of the producing GOR, especially in low GOR wells. Therefore, for low GOR wells, flow regimes may change rapidly due to the release of gas with the decline of pressure and temperature in the tubing and consequently change the order of the best correlation as listed in Table 8.

\section{Other parameters sensitivity}

Other parameters were investigated to check their uncertainty on the expert system and the error of the calculated pressure by the selected correlation(s). These parameters include API, gas specific gravity and tubing roughness.

Changing the API of the oil by $\pm 10 \%$ had slight effect on both the expert system selection and the calculated pressure drop by the selected correlation. In more than $90 \%$ of the cases, the expert system was successful in picking up the best correlation even with the $\pm 10 \%$ error in API.

For gas specific gravity, changing gas specific gravity with $\pm 10 \%$ had minor effect on changing the order of the best correlation as the expert system predicted the best correlation with $90 \%$. The exception was for low GOR low rate wells, as the expert system could obtain the best correlation with only $37.5 \%$.

For tubing roughness, the expert system could obtain the best correlations $95 \%$ of the time. The exception was for high GOR high rate wells, where the expert system could predict the best correlation with only $37.5 \%$.

The selection of the range of sensitivity analysis parameters was mainly based on measurement errors in operations of oil fields. GOR measurement error may reach $\pm 20 \%$, while API and specific gravity of gas are usually estimated with much more certainty. Table 8 summarizes the results of the sensitivity analysis of these parameters and their effect on changing the order of the best correlation and consequently the capability of the expert system to predict the best correlation even with some measurements errors.

\section{Conclusions}

We utilized a large dataset to test the accuracy of 14 correlations among the most widely used multiphase flow correlations. We also used an approach to take advantage of the fact that each correlation is strong under certain conditions of well geometry, flow conditions, and PVT properties. The approach is based on data clustering. The following conclusions can be made:
Table 8 Effect of different sensitive parameters on correlation prediction

\begin{tabular}{lllll}
\hline Well flow condition & GOR effect & API effect & $\begin{array}{l}\text { Gas specific } \\
\text { gravity effect }\end{array}$ & $\begin{array}{l}\text { Tubing } \\
\text { roughness } \\
\text { effect }\end{array}$ \\
\hline Low GOR and high production rate & Medium & Low & Low & Low \\
Low GOR and low production rate & High & Low & High & Low \\
High GOR and high production rate & Low & Low & Medium & Medium \\
High GOR and low production rate & Low & Low & Low & Low \\
\hline
\end{tabular}


1. The overall mean absolute percent error is around $12.7 \%$ for the best multiphase flow correlation in the entire dataset, while the range of errors for the best correlation(s) in different data sub-clusters is from 0.01 to $3 \%$ for most cases with accurate PVT.

2. In the validation dataset, the mean absolute percent error was $8.8 \%$ when the expert system was used. This represents approximately one-third of the error value when any single correlation is used over the entire dataset. (Error for using single correlation ranges from more than 21 to $29 \%$.)

3. From the sensitivity runs, we found that GOR, API, and gas specific gravity may have different degrees of effectiveness on the correlation selection. PVT data are probably one of the most important multiphase flow correlations input data affecting the accuracy of the correlation.

4. In practice, an accurate gas rate should be determined through production test separator especially for low rate oil wells as GOR has important effect on pressure drop results. GOR was found to have impact on changing the best correlations for different clusters of oil data in case of low GOR wells. However, GOR has minor effect on selection of best correlations for high GOR wells.

5. Tubing roughness was found to have small impact on changing the best correlations for different clusters of oil well data (except for high GOR and high oil rate wells).

Open Access This article is distributed under the terms of the Creative Commons Attribution 4.0 International License (http://creativeco mmons.org/licenses/by/4.0/), which permits unrestricted use, distribution, and reproduction in any medium, provided you give appropriate credit to the original author(s) and the source, provide a link to the Creative Commons license, and indicate if changes were made.

\section{Appendix (A)}

To use the expert system, the user needs to collect the well information and flow conditions. Required well information is: (1) well depth, (2) well type (vertical, deviated, or horizontal), and (3) tubing ID. Required flow conditions are: (4) oil rate, (5) water cut, and (6) producing GOR. The well information is used with the clusters map presented in Fig. 3 to define the data cluster. Then flow conditions are used to define the "sub-cluster" reference number from Table 4 . The reference number is then used with the set of tables in this appendix (Tables 9, 10, 11, 12, 13, 14, 15, 16, 17, 18, 19, 20,
Table 9 Best correlations for cluster (A)

\begin{tabular}{lllll}
\hline Sub-cluster & Total points & Correlation & $\begin{array}{l}\text { Strength } \\
\text { factor } \\
\text { "\%” }\end{array}$ & $\begin{array}{l}\text { Mean absolute } \\
\text { percent error } \\
\text { "\%" }\end{array}$ \\
\hline A1 & 29 & PET 5/GRE & 31 & 1.9 \\
& & MB & 28 & 2.1 \\
A2 & 2 & ORK & 100 & 1.0 \\
A3 & 6 & GRE/PET 5 & 33 & 0.9 \\
& & PET 2 & 33 & 1.0 \\
& & PET 4 & 33 & 1.4 \\
& & HYDRO & 33 & 2.4 \\
& & BEGG & 33 & 2.5 \\
& & ORK & 33 & 15.7 \\
A8 & 4 & MB & 33 & 25.9 \\
A13 & 22 & BEGG & 75 & 3.2 \\
& & GRE & 82 & 1.9 \\
\hline
\end{tabular}

Table 10 Best correlations for cluster (B)

\begin{tabular}{|c|c|c|c|c|}
\hline Sub-cluster & Total points & Correlation & $\begin{array}{l}\text { Strength } \\
\text { factor } \\
\text { "\%" }\end{array}$ & $\begin{array}{l}\text { Mean absolute } \\
\text { percent error "\%" }\end{array}$ \\
\hline \multirow[t]{3}{*}{ B1 } & \multirow[t]{3}{*}{73} & PET 5 & 37 & 0.9 \\
\hline & & PET 4 & 36 & 0.9 \\
\hline & & GRE & 34 & 0.8 \\
\hline B2 & 42 & ORK & 31 & 2.5 \\
\hline \multirow[t]{3}{*}{ B3 } & \multirow[t]{3}{*}{168} & MB & 42 & 2.9 \\
\hline & & GRE & 39 & 2.7 \\
\hline & & PET 5 & 39 & 2.7 \\
\hline \multirow[t]{3}{*}{ B4 } & \multirow[t]{3}{*}{13} & DRM & 38 & 1.9 \\
\hline & & PET 2 & 31 & 0.4 \\
\hline & & PET 5 & 31 & 0.6 \\
\hline \multirow[t]{2}{*}{ B5 } & \multirow[t]{2}{*}{7} & PET 3 & 57 & 1.8 \\
\hline & & PET 5 & 43 & 1.8 \\
\hline B6 & 2 & DRO & 100 & 2.3 \\
\hline \multirow[t]{2}{*}{ B7 } & \multirow[t]{2}{*}{24} & BEGG & 75 & 27.2 \\
\hline & & DRO & 67 & 29.9 \\
\hline \multirow[t]{2}{*}{ B13 } & \multirow[t]{2}{*}{69} & PET 5 & 64 & 1.2 \\
\hline & & GRE & 62 & 1.1 \\
\hline \multirow[t]{2}{*}{ B14 } & \multirow[t]{2}{*}{14} & BEGG & 50 & 1.9 \\
\hline & & PET & 50 & 2.4 \\
\hline \multirow[t]{3}{*}{ B15 } & \multirow[t]{3}{*}{5} & GRE & 40 & 1.2 \\
\hline & & PET 2 & 40 & 1.8 \\
\hline & & BEGG & 40 & 2.0 \\
\hline
\end{tabular}


Table 11 Best correlations for cluster (C)

\begin{tabular}{|c|c|c|c|c|}
\hline Sub-cluster & Total points & Correlation & $\begin{array}{l}\text { Strength } \\
\text { factor } \\
\text { "\%" }\end{array}$ & $\begin{array}{l}\text { Mean absolute } \\
\text { percent error "\%" }\end{array}$ \\
\hline \multirow[t]{2}{*}{$\mathrm{C} 1$} & \multirow[t]{2}{*}{99} & PET 3 & 29 & 5.8 \\
\hline & & DRO & 26 & 8.4 \\
\hline \multirow[t]{2}{*}{$\mathrm{C} 2$} & \multirow[t]{2}{*}{30} & FB & 47 & 6.3 \\
\hline & & ORK & 47 & 6.6 \\
\hline \multirow[t]{2}{*}{ C3 } & \multirow[t]{2}{*}{28} & BEGG & 54 & 4.6 \\
\hline & & $\mathrm{MB}$ & 54 & 14.3 \\
\hline $\mathrm{C} 4$ & 9 & HYDRO & 56 & 19.6 \\
\hline \multirow[t]{2}{*}{$\mathrm{C} 5$} & \multirow[t]{2}{*}{17} & $\mathrm{MB}$ & 53 & 4.5 \\
\hline & & BEGG & 47 & 5.7 \\
\hline C6 & 1 & DRO & 100 & 28.61 \\
\hline \multirow[t]{4}{*}{$\mathrm{C} 8$} & \multirow[t]{4}{*}{2} & DRM & 50 & 1.0 \\
\hline & & PET 2 & 50 & 1.6 \\
\hline & & BEGG & 50 & 2.0 \\
\hline & & ORK & 50 & 18.9 \\
\hline $\mathrm{C} 10$ & 1 & DRO & 100 & 1.59 \\
\hline \multirow[t]{2}{*}{$\mathrm{C} 11$} & \multirow[t]{2}{*}{1} & GRE & 100 & 0.05 \\
\hline & & PET 5 & 100 & 0.1 \\
\hline \multirow[t]{2}{*}{$\mathrm{C} 12$} & \multirow[t]{2}{*}{8} & PET 2 & 63 & 8.7 \\
\hline & & BEGG & 63 & 11.3 \\
\hline \multirow[t]{2}{*}{$\mathrm{C} 13$} & \multirow[t]{2}{*}{36} & GRE & 58 & 2.1 \\
\hline & & PET 5 & 58 & 2.5 \\
\hline $\mathrm{C} 15$ & 1 & DRO & 100 & 1.0 \\
\hline $\mathrm{C} 25$ & 1 & DRM & 100 & 1.3 \\
\hline
\end{tabular}

21) to define the best correlation, its strength factor, and its mean absolute percent error. An example for the use of the expert system is given in "Appendix B."

Tables through 9, 10, 11, 12, 13, 14, 15, 16, 17, 18, 19, 20 , and 21 show detailed results of the best correlation(s) for the different data clusters.

\section{Appendix (B)}

\section{Example}

A vertical well is completed with a 2.375 in ID tubing, and gauge depth of 12,024 feet is flowing oil at a rate of $282 \mathrm{bbl} / \mathrm{D}$ with $0 \%$ water cut and $699 \mathrm{scf} / \mathrm{bbl}$ GOR. Use the
Table 12 Best correlations for cluster (D)

\begin{tabular}{|c|c|c|c|c|}
\hline Sub-cluster & Total points & Correlation & $\begin{array}{l}\text { Strength } \\
\text { factor } \\
\text { "\%" }\end{array}$ & $\begin{array}{l}\text { Mean absolute } \\
\text { percent error "\%" }\end{array}$ \\
\hline \multirow[t]{3}{*}{ D1 } & \multirow[t]{3}{*}{154} & GRE & 34 & 1.7 \\
\hline & & PET 5 & 30 & 1.5 \\
\hline & & PET 4 & 29 & 1.4 \\
\hline \multirow[t]{4}{*}{ D2 } & \multirow[t]{4}{*}{137} & FB & 30 & 3.1 \\
\hline & & $\mathrm{HB}$ & 28 & 3.2 \\
\hline & & ORK & 26 & 6.3 \\
\hline & & GRE & 24 & 2.2 \\
\hline \multirow[t]{4}{*}{ D3 } & \multirow[t]{4}{*}{414} & BEGG & 35 & 1.4 \\
\hline & & DRO & 34 & 1.7 \\
\hline & & PET 4 & 33 & 1.3 \\
\hline & & GRE & 32 & 1.3 \\
\hline \multirow[t]{2}{*}{ D4 } & \multirow[t]{2}{*}{60} & MB & 63 & 5.1 \\
\hline & & $\mathrm{HB}$ & 62 & 5.3 \\
\hline \multirow[t]{2}{*}{ D5 } & \multirow[t]{2}{*}{16} & PET 3 & 38 & 4.3 \\
\hline & & ORK & 31 & 2.7 \\
\hline D6 & 10 & DRO & 60 & 6.2 \\
\hline D7 & 84 & ORK & 80 & 18.9 \\
\hline \multirow[t]{2}{*}{ D10 } & \multirow[t]{2}{*}{1} & ORK & 100 & 8.4 \\
\hline & & HYDRO & 100 & 8.7 \\
\hline \multirow[t]{3}{*}{ D13 } & \multirow[t]{3}{*}{118} & PET & 31 & 0.9 \\
\hline & & PET 2 & 29 & 1.3 \\
\hline & & GRE & 28 & 1.0 \\
\hline D14 & 37 & BEGG & 57 & 2.1 \\
\hline \multirow[t]{2}{*}{ D15 } & \multirow[t]{2}{*}{12} & DRO & 50 & 0.7 \\
\hline & & BEGG & 42 & 0.9 \\
\hline D17 & 1 & FB & 100 & 0.8 \\
\hline D25 & 2 & ORK & 100 & 2.2 \\
\hline
\end{tabular}

expert system to find the best correlation and its expected accuracy.

Using Fig. 3 in the paper, the well lies in data cluster E. With the flow conditions, we find from Table 4 the sub-cluster reference number to be 1 . Therefore, the data given in this example lie in sub-cluster E1. We use Table 13 because it represents the data cluster for this point; then, we go to row 1 , which represents the sub-cluster. We find from this table that the best correlation is MB with expected mean absolute percent error of $5.76 \%$. Notice that this mean absolute percent error was the error for this best correlation over the 
Table 13 Best correlations for cluster (E)

\begin{tabular}{|c|c|c|c|c|}
\hline Sub-cluster & Total points & Correlation & $\begin{array}{l}\text { Strength } \\
\text { factor } \\
\text { "\%" }\end{array}$ & $\begin{array}{l}\text { Mean absolute } \\
\text { percent error "\%" }\end{array}$ \\
\hline \multirow[t]{2}{*}{ E1 } & \multirow[t]{2}{*}{25} & MB & 72 & 5.8 \\
\hline & & BEGG & 56 & 6.6 \\
\hline \multirow[t]{3}{*}{ E2 } & \multirow[t]{3}{*}{1} & DRM & 100 & 1.53 \\
\hline & & PET 4 & 100 & 1.88 \\
\hline & & PET 5 & 100 & 1.95 \\
\hline \multirow[t]{3}{*}{ E3 } & \multirow[t]{3}{*}{9} & DRM & 56 & 0.7 \\
\hline & & ORK & 44 & 1.43 \\
\hline & & HYDRO & 44 & 1.81 \\
\hline E5 & 19 & DRM & 42 & 2.0 \\
\hline E6 & 2 & ORK & 100 & 1.6 \\
\hline E9 & 2 & HYDRO & 100 & 2.4 \\
\hline \multirow[t]{3}{*}{ E13 } & \multirow[t]{3}{*}{4} & PET 4 & 100 & 4.5 \\
\hline & & FB & 100 & 4.5 \\
\hline & & PET 3 & 100 & 4.5 \\
\hline \multirow[t]{2}{*}{ E14 } & \multirow[t]{2}{*}{3} & $\mathrm{FB}$ & 100 & 46.08 \\
\hline & & ORK & 100 & 47.41 \\
\hline E15 & 5 & $\mathrm{HB}$ & 100 & 131.75 \\
\hline E18 & 2 & ORK & 100 & 5.1 \\
\hline E25 & 7 & HYDRO & 100 & 143.03 \\
\hline E26 & 4 & $\mathrm{HB}$ & 100 & 122.64 \\
\hline \multirow[t]{3}{*}{ E29 } & \multirow[t]{3}{*}{1} & PET 3 & 100 & 14.4 \\
\hline & & PET 2 & 100 & 13.3 \\
\hline & & BEGG & 100 & 11.3 \\
\hline
\end{tabular}

Table 14 Best correlations for cluster $(\mathrm{F})$

\begin{tabular}{|c|c|c|c|c|}
\hline Sub-cluster & Total points & Correlation & $\begin{array}{l}\text { Strength } \\
\text { factor } \\
\text { "\%" }\end{array}$ & $\begin{array}{l}\text { Mean absolute } \\
\text { percent error "\%" }\end{array}$ \\
\hline \multirow[t]{3}{*}{$\mathrm{F} 1$} & \multirow[t]{3}{*}{9} & FB & 89 & 2.7 \\
\hline & & GRE & 89 & 3.5 \\
\hline & & PET 4 & 89 & 3.6 \\
\hline $\mathrm{F} 2$ & 6 & ORK & 100 & 10.3 \\
\hline \multirow[t]{2}{*}{ F3 } & \multirow[t]{2}{*}{5} & FB & 100 & 0.8 \\
\hline & & $\mathrm{HB}$ & 100 & 1.3 \\
\hline \multirow[t]{3}{*}{ F4 } & \multirow[t]{3}{*}{8} & FB & 100 & 0.1 \\
\hline & & BEGG & 100 & 0.4 \\
\hline & & PET4 & 100 & 0.5 \\
\hline \multirow[t]{2}{*}{ F5 } & \multirow[t]{2}{*}{4} & PET 4 & 100 & 0.6 \\
\hline & & PET 3 & 100 & 0.6 \\
\hline \multirow[t]{2}{*}{ F6 } & \multirow[t]{2}{*}{1} & PET 4 & 100 & 0.2 \\
\hline & & PET 5 & 100 & 0.5 \\
\hline F6 & 14 & ORK & 71 & 15.6 \\
\hline F13 & 10 & DRM & 50 & 4.6 \\
\hline F17 & 2 & DRM & 100 & 1.1 \\
\hline \multirow[t]{2}{*}{ F29 } & \multirow[t]{2}{*}{2} & DRM & 100 & 1.1 \\
\hline & & BEGG & 100 & 2.0 \\
\hline
\end{tabular}

Table 15 Best correlations for cluster $(\mathrm{G})$

\begin{tabular}{|c|c|c|c|c|}
\hline Sub-Cluster & Total points & Correlation & $\begin{array}{l}\text { Strength } \\
\text { factor } \\
\text { "\%" }\end{array}$ & $\begin{array}{l}\text { Mean absolute } \\
\text { percent error } \\
\text { "\%" }\end{array}$ \\
\hline G1 & 23 & FB & 65 & 1.4 \\
\hline \multirow[t]{3}{*}{ G2 } & \multirow[t]{3}{*}{19} & PET & 58 & 1.5 \\
\hline & & $\mathrm{HB}$ & 53 & 1.5 \\
\hline & & PET 3 & 53 & 1.6 \\
\hline G3 & 17 & MB & 53 & 1.5 \\
\hline G4 & 4 & DRM & 50 & 1.7 \\
\hline G7 & 2 & FB & 100 & 23.3 \\
\hline G8 & 2 & DRO & 100 & 5.0 \\
\hline \multirow[t]{3}{*}{ G11 } & \multirow[t]{3}{*}{2} & $\mathrm{HB}$ & 100 & 47.0 \\
\hline & & FB & 100 & 47.0 \\
\hline & & PET 3 & 100 & 47.3 \\
\hline G12 & 3 & DRO & 67 & 35.1 \\
\hline \multirow[t]{3}{*}{ G13 } & \multirow[t]{3}{*}{7} & $\mathrm{HB}$ & 100 & 0.6 \\
\hline & & GRE & 71 & 0.4 \\
\hline & & PET 5 & 71 & 0.5 \\
\hline \multirow[t]{2}{*}{ G17 } & \multirow[t]{2}{*}{4} & $\mathrm{HB}$ & 100 & 1.2 \\
\hline & & PET 4 & 75 & 1.4 \\
\hline
\end{tabular}

Table 16 Best correlations for cluster $(\mathrm{H})$

\begin{tabular}{lllll}
\hline Sub-cluster & Total points & Correlation & $\begin{array}{l}\text { Strength } \\
\text { factor } \\
\text { "\%” }\end{array}$ & $\begin{array}{l}\text { Mean absolute } \\
\text { percent error “\%” }\end{array}$ \\
\hline H1 & 23 & DRO & 65 & 1.2 \\
& & ORK & 52 & 1.8 \\
H2 & 7 & DRO & 57 & 1.3 \\
& & DRM & 57 & 3.9 \\
H3 & 7 & DRO & 100 & 5.6 \\
& & DRM & 86 & 5.7 \\
H4 & 6 & DRM & 50 & 1.4 \\
& & DRO & 50 & 2.3 \\
& & GRE & 33 & 1.4 \\
& & PET 5 & 33 & 1.5 \\
H5 & 1 & MB/BEGG & 100 & 1.94 \\
H13 & 3 & ORK & 100 & 2.3 \\
H17 & 2 & BEGG & 50 & 0.5 \\
& & DRM & 50 & 1.2 \\
\hline
\end{tabular}


Table 17 Best correlations for cluster (I)

\begin{tabular}{|c|c|c|c|c|}
\hline Sub-cluster & Total points & Correlation & $\begin{array}{l}\text { Strength } \\
\text { factor } \\
\text { "\%" }\end{array}$ & $\begin{array}{l}\text { Mean absolute } \\
\text { percent error "\%" }\end{array}$ \\
\hline \multirow[t]{2}{*}{ I1 } & \multirow[t]{2}{*}{84} & MB & 43 & 1.5 \\
\hline & & HYDRO & 35 & 2.2 \\
\hline \multirow[t]{3}{*}{ I2 } & \multirow[t]{3}{*}{52} & PET 3 & 48 & 1.1 \\
\hline & & FB & 44 & 1.7 \\
\hline & & $\mathrm{HB}$ & 42 & 1.6 \\
\hline \multirow[t]{2}{*}{ I3 } & \multirow[t]{2}{*}{108} & BEGG & 35 & 2.4 \\
\hline & & DRM & 34 & 5.2 \\
\hline \multirow[t]{2}{*}{ I4 } & \multirow[t]{2}{*}{25} & $\mathrm{MB}$ & 64 & 6.4 \\
\hline & & GRE & 60 & 6.5 \\
\hline I5 & 69 & DRM & 67 & 2.3 \\
\hline I6 & 1 & FB & 100 & 0.3 \\
\hline I7 & 18 & $\mathrm{FB}$ & 67 & 18.7 \\
\hline I8 & 7 & DRM & 43 & 2.1 \\
\hline \multirow[t]{3}{*}{ I9 } & \multirow[t]{3}{*}{7} & DRO & 100 & 0.4 \\
\hline & & $\mathrm{FB}$ & 71 & 0.8 \\
\hline & & PET 4 & 71 & 1.2 \\
\hline \multirow[t]{2}{*}{ I10 } & \multirow[t]{2}{*}{4} & GRE & 100 & 3.5 \\
\hline & & PET 4 & 50 & 2.6 \\
\hline \multirow[t]{3}{*}{ I11 } & \multirow[t]{3}{*}{6} & FB & 83 & 7.7 \\
\hline & & HB & 83 & 7.7 \\
\hline & & PET 3 & 83 & 8.3 \\
\hline $\mathrm{I} 12$ & 25 & PET 2 & 40 & 7.2 \\
\hline I13 & 24 & $\mathrm{FB}$ & 50 & 1.5 \\
\hline \multirow[t]{3}{*}{ I14 } & \multirow[t]{3}{*}{5} & $\mathrm{MB}$ & 80 & 0.6 \\
\hline & & PET 4 & 80 & 0.9 \\
\hline & & PET & 80 & 1.4 \\
\hline \multirow[t]{2}{*}{ I17 } & \multirow[t]{2}{*}{3} & PET 4 & 100 & 0.6 \\
\hline & & PET 5 & 67 & 0.7 \\
\hline \multirow[t]{2}{*}{ I19 } & \multirow[t]{2}{*}{1} & ORK & 100 & 1.5 \\
\hline & & $\mathrm{FB}$ & 100 & 2.3 \\
\hline \multirow[t]{3}{*}{$\mathrm{I} 25$} & \multirow[t]{3}{*}{23} & $\mathrm{FB}$ & 74 & 1.7 \\
\hline & & $\mathrm{HB}$ & 74 & 1.8 \\
\hline & & ORK & 57 & 1.6 \\
\hline
\end{tabular}

Table 18 Best correlations for cluster (J)

\begin{tabular}{llllc}
\hline Sub-cluster & Total points & Correlation & $\begin{array}{l}\text { Strength } \\
\text { factor } \\
\text { "\%" }\end{array}$ & $\begin{array}{l}\text { Mean absolute } \\
\text { percent error “\%" }\end{array}$ \\
\hline J1 & 2 & ORK/DRM & 50 & 2.0 \\
J5 & 4 & PET 3 & 50 & 2.5 \\
& & DRM & 50 & 31.4 \\
J7 & 2 & PET 3 & 50 & 0.0 \\
& & BEGG & 50 & 3.1 \\
J12 & 1 & BEGG & 100 & 24.0 \\
J17 & 1 & BEGG & 100 & 3.4 \\
& & DRM & 100 & 3.5 \\
\hline
\end{tabular}

Table 19 Best correlations for cluster (K)

\begin{tabular}{|c|c|c|c|c|}
\hline Sub-cluster & Total points & Correlation & $\begin{array}{l}\text { Strength } \\
\text { factor } \\
\text { "\%" }\end{array}$ & $\begin{array}{l}\text { Mean absolute } \\
\text { percent error "\%" }\end{array}$ \\
\hline K1 & 2 & ORK & 100 & 8.4 \\
\hline $\mathrm{K} 2$ & 1 & ORK & 100 & 0.6 \\
\hline \multirow[t]{2}{*}{ K6 } & \multirow[t]{2}{*}{7} & PET 2 & 43 & 1.6 \\
\hline & & PET 3 & 29 & 0.4 \\
\hline K7 & 14 & FB & 57 & 11.9 \\
\hline \multirow[t]{2}{*}{ K8 } & \multirow[t]{2}{*}{6} & $\mathrm{MB}$ & 50 & 2.3 \\
\hline & & BEGG & 50 & 4.8 \\
\hline \multirow[t]{2}{*}{ K10 } & \multirow[t]{2}{*}{2} & GRE & 100 & 0.7 \\
\hline & & PET 5 & 100 & 1.0 \\
\hline \multirow[t]{2}{*}{ K12 } & \multirow[t]{2}{*}{19} & BEGG & 53 & 22.7 \\
\hline & & DRM & 42 & 30.7 \\
\hline \multirow[t]{3}{*}{ K13 } & \multirow[t]{3}{*}{8} & ORK & 88 & 14.3 \\
\hline & & $\mathrm{HB}$ & 63 & 13.7 \\
\hline & & PET 3 & 63 & 14.4 \\
\hline \multirow[t]{2}{*}{ K17 } & \multirow[t]{2}{*}{16} & $\mathrm{HB}$ & 67 & 2.2 \\
\hline & & PET 2 & 63 & 2.3 \\
\hline \multirow[t]{2}{*}{ K21 } & \multirow[t]{2}{*}{1} & PET 2 & 100 & 0.4 \\
\hline & & MB & 100 & 0.9 \\
\hline \multirow[t]{3}{*}{ K25 } & \multirow[t]{3}{*}{5} & ORK & 100 & 2.6 \\
\hline & & FB & 100 & 2.7 \\
\hline & & $\mathrm{HB}$ & 100 & 2.8 \\
\hline \multirow[t]{2}{*}{ K29 } & \multirow[t]{2}{*}{18} & PET 2 & 56 & 0.9 \\
\hline & & PET 3 & 56 & 1.1 \\
\hline \multirow[t]{2}{*}{ K33 } & \multirow[t]{2}{*}{1} & BEGG & 100 & 0.2 \\
\hline & & ORK & 100 & 0.6 \\
\hline
\end{tabular}

Table 20 Best correlations for cluster (L)

\begin{tabular}{lllrr}
\hline Sub-cluster & Total points & Correlation & $\begin{array}{l}\text { Strength } \\
\text { factor } \\
\text { "\%" }\end{array}$ & $\begin{array}{l}\text { Mean absolute } \\
\text { percent error "\%" }\end{array}$ \\
\hline L1 & 6 & DRM & 50 & 2.5 \\
& & FB & 50 & 10.2 \\
L3 & \multirow{2}{*}{4} & BEGG & 100 & 1.0 \\
& & DRO & 75 & 1.1 \\
& \multirow{2}{*}{8} & MB & 75 & 1.2 \\
L13 & \multirow{2}{*}{2} & PET 3 & 75 & 0.3 \\
& & HB & 75 & 0.7 \\
L14 & HYDRO & 100 & 1.0 \\
& & BEGG & 50 & 0.0 \\
& \multirow{2}{*}{2} & PET 2 & 50 & 0.6 \\
L25 & & BEGG & 100 & 2.4 \\
& & DRO & 50 & 3.1 \\
\hline
\end{tabular}


Table 21 Best correlations for cluster (M)

\begin{tabular}{lclcl}
\hline Sub-cluster & Total points & Correlation & $\begin{array}{l}\text { Strength } \\
\text { factor } \\
\text { "\%” }\end{array}$ & $\begin{array}{l}\text { Mean absolute } \\
\text { percent error “\%" }\end{array}$ \\
\hline M1 & 10 & ORK & 60 & 21.8 \\
M3 & 6 & DRO & 100 & 0.7 \\
M13 & 16 & PET 3 & 69 & 0.2 \\
& & MB & 69 & 0.7 \\
M14 & 7 & BEGG & 100 & 0.2 \\
& & HYDRO & 100 & 0.3 \\
& & DRO & 86 & 0.9 \\
M25 & 6 & DRO & 100 & 1.9 \\
& & BEGG & 100 & 2.7 \\
\hline
\end{tabular}

Table 22 Calculated pressure and absolute percent error from different correlations compared to actual data

\begin{tabular}{lll}
\hline Correlation & $\begin{array}{l}\text { Calculated pressure, } \\
\text { psi }\end{array}$ & $\begin{array}{l}\text { Absolute } \\
\text { percent } \\
\text { error, \% }\end{array}$ \\
\hline Measured (actual) & 2985 & - \\
MB (predicted by expert & 3066.57 & 2.7 \\
$\quad$ system) & 3210.15 & 7.5 \\
DRM & 2734.28 & 8.4 \\
HB & 2673.61 & 10.4 \\
FB & 3317.26 & 11.1 \\
BEGG & 2806.17 & 6.0 \\
PET & 3256.22 & 9.1 \\
ORK & 2897.19 & 2.9 \\
PET 2 & 3354.18 & 12.4 \\
DRO & 2796.87 & 6.3 \\
PET 3 & 3297.77 & 10.5 \\
GRE & 3313.33 & 11.0 \\
PET 4 & 3389.8 & 13.6 \\
HYDRO & 3281 & 9.9 \\
PET 5 & &
\end{tabular}

available data points within this sub-cluster. The available data points are 25 (which are also given in Table 13).

We used the suggested correlation by the expert system to calculate the bottom-hole flowing pressure for this well from the tubing head pressure and PVT data. The calculated pressure by the chosen correlation was 3066.57 psi with absolute percent error $2.7 \%$. Table 22 gives the calculated pressure and absolute percent error by the expert system chosen correlation (MB) compared with the measured pressure and the calculated pressure by other correlations.

\section{References}

Abd El-Moniem MA (2016) Evaluation and proper selection of multiphase flow correlations. MS Thesis, Cairo University, Egypt

Abd El-Moniem MA, El-Banbi AH (2015) Proper selection of multiphase flow correlations. In: SPE 175805 presented at North Africa technical conference and exhibition, Cairo, 14-16 Sept

Ansari AM, Sylvester ND, Shoham O, Brill JP (1990) A comprehensive mechanistic model for upward two phase flow in wellbores. In: SPE 20630 presented at the 65th annual technical conference and exhibition, New Orleans, 23-26 Sept, pp 151-165

Ashiem H (1986) MONA, an accurate two phase well flow model based on phase slippage. In: SPE 12989, SPE production engineering, May, pp 221-230

Aziz K, Govier GW, Fogarasi M (1972) Pressure drop in wells producing oil and gas. J Can Pet 11:38-48

Baxendell PB, Thomas R (1961) The calculation of pressure gradients in high rate flowing wells. J Pet Technol 13:1023-1028

Beggs HD, Brill JP (1973) A study of two phase flow in inclined pipes. J Pet Technol 25:607-617

Chierici GL, Ciucci GM, Sclocchi G (1974) Two phase vertical flow in oil wells prediction of pressure drop. J Pet Technol 26:927-938

Duns H Jr., Ros NCJ (1963) Vertical flow of gas and liquid mixtures in wells. In: Section II, Paper 22-PD 6, proceedings of the sixth world petroleum congress, Frankfurt, 19-26 June, pp 451-465

Fancher GH Jr, Brown KE (1963) Prediction of pressure gradients for multiphase flow in tubing. Soc Pet Eng J 3:59-69

Gray HE (1978) Vertical flow correlation in gas wells, user's manual for API 14B surface controlled subsurface safety valve sizing computer program, 2nd edn. American Petroleum Institute, Dallas (Appendix B)

Hagedorn AR, Brown KE (1964) The effect of liquid viscosity in two phase vertical flow. J Pet Technol 16:203-210

Hagedorn AR, Brown KE (1965) Experimental study of pressure gradients occurring during continuous two phase flow in small diameter vertical conduits. J Pet Technol 17:475-484

Hill TJ, Wood DG (1994) Slug flow: occurrence, consequences, and prediction. In: SPE 27960 presented at the University of Tulsa Petroleum Engineering symposium, OK, USA, 29-31 Aug, pp $53-62$

Mukherjee H, Brill JP (1983) Liquid holdup correlations for inclined two phase flow. J Pet Technol 35:1003-1008

Orkiszewski J (1967) Predicting two phase pressure drops in vertical pipe. J Pet Technol 19:829-838

Peffer JW, Miller MA, Hill AD (1988) An improved method for calculating bottomhole pressures in flowing gas wells with liquid present. In: SPE production engineering, November, pp 643-655

Poettmann FH, Carpenter PJ (1952) The multiphase flow of gas, oil and water through vertical flow string with the application of the design of gas lift installation. Drilling and Production Practice. American Petroleum Institute, New York

Prosper Software Help Manual, Petroleum Experts (2013)

Reinicke KM, Remer RJ, Hueni G (1987) Comparison of measured and predicted pressure drops in tubing for high water cut gas wells. In: SPE production engineering, August, pp 165-177

Publisher's Note Springer Nature remains neutral with regard to jurisdictional claims in published maps and institutional affiliations. 